\title{
ANATOMY OF REFORMISM: THE SOCIAL AND POLITICAL IDEAS OF THE LABOUR LEADERSHIP IN YORKSHIRE
}

Critiques of the history of British Socialism tend to begin with the assumption that the Labour movement preferred evolution to revolution, reform to fundamental change. The local Labour leadership is alleged to have responded to the difficulties of radical politics between 1880 and 1920 by tamely following a policy of tactical moderation devised in London by the Parliamentary front bench.

On the basis of a survey of the men and ideas of the Labour movement in Yorkshire this article contends that the "reformism" of the local leaders was arrived at by autonomous argument arising as much from shared theory and belief as from disappointment and expediency. The consensus which MacDonald, Snowden and Thomas are said to have forced on Labour and then betrayed was, in fact, part of the essential nature of the Labour Party. Indeed, it was the emergence of such a consensus which made possible the accommodation of the Labour movement's sectarian and democratic strands, and the rise of a national Labour Party.

This agreement did not depend upon a choice between moderation and extremism. Local leaders did not suggest reforming capitalism as an alternative to wrecking it. Instead, they planned to reform both the men who organised capitalism and those who lived and worked under it. The people were to be educated in Socialism, to be prepared for the new social order that would follow the technological and scientific developments industry was itself evolving and by which it would be improved.

The first part of the article investigates the social and political background of the local leadership, in an attempt to explain their shared outlook and attitudes, while the second examines the nature and implications of their ideas.

The difficulty of tracking down the ideas and beliefs of ordinary working men has disguised the intellectual liveliness and enthusiasm which characterised the Labour movement after 1900. Something of 
its vitality is suggested by this extract from a report of a socialist meeting in Huddersfield: "The close intimacy with, and apt quotations from Marx, Bax, Morris, Ruskin, Blatchford, Labriola [...] would have turned green with envy the habitués of our conventional political clubs, who strive in vain to imbue their youngsters with some sort of mock animation."'1

Despite the varied educational and occupational backgrounds of the local leadership, a considerable number of them arrived at remarkably similar conclusions about the problems which faced them. Among these leaders, two main groups can be distinguished on biographical grounds - the "old" Socialists who served in the Independent Labour Party from the 1890s, and the ex-Liberals who came into the ILP in 1918 as a result of their contact with Labour leaders in the peace movement, and disillusionment with Liberal politics. But both were inspired by the demand for justice for the masses, and the awareness that only genuine democracy could achieve it.

Philip Snowden and Fred Jowett were central figures in the former group. They both chaired the ILP for three-year terms, and belonged to the National Administrative Council from its earliest days. They were born in the same year (1864) and served together in the first Labour cabinet. Jowett's base was in Bradford, where he had been instrumental in setting up the Workers' Municipal Federation in 1912. Snowden wrote more books, rivalling MacDonald as a Socialist sage and excelling as a speech-maker. Both were elected to Parliament in 1906, and lost their seats in 1918, after four unpopular years in which they uncompromisingly opposed the war. Afterwards, they led the Labour attack on the Treaty of Versailles, denouncing the reparations clauses and the militarist "spirit". Jowett went back to Bradford as secretary to the ILP, and Snowden became a journalist, writing a series of articles for the Labour Leader.

Less well-known to the general public, but equally important in building up the local movement after the war, was Wilfrid Whiteley. He was highly esteemed by his colleagues: "Mr. Whiteley's name is almost a household word in local Socialist circles, while in a much wider sphere in Yorkshire and the County palatine he is well-known as a platform protagonist of democratic principles." $2 \mathrm{He}$ was eighteen years younger than Jowett and Snowden, and did not come into prominence until he became President of the Huddersfield ILP Federation in 1916. His work in the local peace movement, as secretary

1 The Worker (Huddersfield), 1913, press cutting headed "Economics v. Ethics", Fred Shaw Papers (photocopies in York University Library).

2 The Worker, 27.4.18. 
to the Huddersfield Council for Civil Liberties, won him a reputation as an organiser and in 1918 he was Labour candidate for Colne Valley, and afterwards secretary-agent to the Huddersfield Labour Party. He was an "ethical" socialist, and was much attracted by the moral fervour of ILP platforms. His brother-in-law had introduced him to Clarion literature, and before long he was speaking at every opportunity: "I got more and more opportunity for speaking, particularly in the Christian Endeavour movement at that time, and also in the Band of Hope Movement, with Marsh Methodists."1

$\mathrm{J}$. H. Hudson, born in 1881 , was a more solidly middle class figure, a Manchester MA and Cobden prize winner, and President of the Salford branch of the National Union of Teachers. His father had been a Socialist Wesleyan schoolmaster, and the mixture of Socialist and Christian idealism persisted in his political work. Internationalism, pacifism, and temperance occupied most of his waking hours. He was co-founder of the No-Conscription Fellowship and served two-and-ahalf years' imprisonment for his refusal to accept exemption from the army on occupational grounds. After the war he was special commissioner for the Union of Democratic Control from 1919-21, and represented the ILP at the Vienna International Conference in 1921. He won Huddersfield in 1923 and began a life-long friendship with Wilfrid Whiteley. He was parliamentary private secretary to Snowden during the second Labour government.

Even more removed from the realities of working class life which prompted Jowett and Whiteley into politics was William Leach. He was a fancy worsted manufacturer of considerable substance, but he was an ILP member as early as 1895, and editor of the Bradford Pioneer ${ }^{2}$ from 1915-19. His attitude reflects very accurately the kind of inhibitions from which local leaders suffered in their attempts to organise a radical working class movement. He wrote to E. D. Morel (with whom he had become associated through the UDC) that: "I have become so acclimatised to the idea of always being associated with a small body acting as the driving, inspiring and directing force of a large one that $I$ have always expected to end my days within a tiny minority." He wanted to see the ILP as a great democratic party of state but could not see "the British democracy with its passion for compromise and middle courses [...] with its absence of idealism [...] ever lending itself wholesale to the promoting of such a movement". 3

1 Cyril Pearce, "An Interview with Wilfred [sic] Whiteley", in: Bulletin of the Society for the Study of Labour History, No 18 (Spring 1969), p. 15.

2 The Bradford ILP newspaper.

3 William Leach to E. D. Morel, 23.7.17, Morel Papers, London School of Economics. 
None of these men were "converted" to Socialism, although some of them afterwards looked for a moment when they had seen light. Their motive was a revulsion from the social and economic condition of the working class, their desire to see a new moral basis for civilisation, and an emotional reaction to injustice and degradation. The ease with which so many of these ILP'ers became absorbed in the work of the peace movement and the post-war initiatives for a new social and international order reflects on the emotional idealism which led them into the Labour movement in the first place.

The ILP in Yorkshire was in the mainstream of the radical dissent of the 1890s and its Socialism, as described by its leading members, resembled nothing so little as a commitment to an inscrutable doctrine. For example, Snowden was content to say that Socialism was "but the application of moral and Christian principles to commercial relationships". ${ }^{1} \mathrm{He}$ is supposed to have been converted to Socialism while reading Kirkup's Inquiry into Socialism in order to refute it, with the result that his "Liberal club lecture turned into a passionate advocacy of the new system". ${ }^{2}$ It is no doubt significant that Snowden claimed the same source for his Socialism as MacDonald ${ }^{3}$ but it is doubtful whether a flash of blinding light was necessary for him to arrive at the view that: "The political democracy dominated by the social ideal will be the coming of Christ to rule the nations in righteousness". ${ }^{4}$ Moral enthusiasm of this kind, directed against crass materialism and the failure of industry to take account of human values, was the common currency of political reformers at the time, and no doubt the ILP's espousal of a "new way of life" attracted many supporters who would have been much less interested in the economic analysis that might have followed on the heels of aesthetic revulsion.

The ex-Liberals, who formed a distinct group of Yorkshire "Socialists" after 1918, and who were taken, at the time, to be representative leaders of those joining Labour, shared many of these emotions and beliefs, but their involvement in the machinery of orthodox Liberalism (and to a lesser extent, their social background) delayed their political transition.

Cecil Wilson, a Sheffield gold and silver refiner, entered the Labour Party at the end of the war. His change of loyalties provides some insight into the factors which led even quite prosperous men and women to consider joining the Labour movement. Wilson's father and grandfather before him had been Liberal MP's, and he had served

${ }^{1}$ Craven Pioneer, November 1893.

${ }^{2}$ Colin Cross, Philip Snowden (1966), p. 21.

3 MacDonald based some of his own work on Kirkup's History of Socialism.

4 Philip Snowden, The Christ that is to be, ILP pamphlet (1903). 
the Liberal Party well himself, as the first secretary of the Yorkshire Liberal Federation, and on Sheffield City Council. His difficulties began when the Government offered the family firm a munitions contract. The company papers record: "On 20th April Cecil [...] stated that he had a conscientious objection to having any responsibility for making what was intended to destroy human life." ${ }^{1} \mathrm{By}$ 1917 he was writing to Oliver Wilson: "I think I ought to let you know that I am very seriously considering applying for membership in one of the Socialist parties."2 Oliver was shocked, and wrote back: "I knew that on matters of the war you and they were drawn somewhat together, it had not entered my head that you were in general sympathy with the general methods and doctrines of any of them. Their aims have always seemed to me high and noble". ${ }^{3}$ This ambiguous note echoed Cecil's own doubts about the Labour Party.

Wilson corresponded with other Liberals, and visited Trevelyan, Gardiner, Leyton Richards and Carl Heath in London. Reporting back to Oliver he wrote: "On the question of what is likely to happen to parties they are all four in pretty general agreement - we shall never go back to the old Liberal Party of pre-war days. The upheaval caused by the war has already settled that." 4 Wilson's hesitation was, apparently, shared by a large number of other Yorkshire Liberals, and his political uncertainty and agonised discussions appear to have been typical.

In a letter to C. P. Trevelyan describing a meeting of radical Liberals at Leeds Wilson wrote: "We did not desire that this meeting should be a large one and consequently the invitations were limited. Thirtythree people were present and nearly as many more who could not come were in thorough sympathy. We had people from Doncaster, Pontefract, Huddersfield, Halifax, Bradford, Shipley, Leeds, Harrogate, Thirsk, Malton, Scarborough, Driffield and York [...] no one desired to remain associated with the Liberal Party [...] perhaps the strongest feeling was expressed in regard to individual liberty and the fear that joining the I.L.P. or Labour Party would very much tie those who did so and cause a curtailment of that individual liberty which we have all valued so fully. [...] If we do not join the Labour Party, in what way can we hope to make our influence felt in any direction, more particularly as it appears that the Radical group has gone over to

1 Memorandum 18.11.15, Sheffield Smelting Company Papers, Sheffield Central Library.

${ }^{2} \mathrm{C}$. H. Wilson to Oliver Wilson, 7.5.17, ibid.

3 Oliver Wilson to C. H. Wilson, 19.5.17, ibid.

* C. H. Wilson to Oliver Wilson, 29.5.17, ibid. 
official Liberalism?"1 In 1923 he justified his decision to join in these terms: "He had pointed out to them that 'Jesus Christ gathered round him some people who were not quite desirable and' said Mr. Wilson with a shrug of his shoulders, 'I may hope to do some good to those I have joined."'2

His interest in politics still flowed from the same motives; there was no intellectual conversion. He found that the ILP did not stand for the unpleasant preconceptions he had held about Socialism, and that its hopes for a new moral world coincided more closely with his own than he could have imagined. The war did not change him, but enabled him to make this discovery. The Labour Leader described the enthusiasm with which he entered into his new role: "Mr. Wilson has lately joined both the Labour Party and the I.L.P. and on Saturday made a striking declaration of his new allegiance, and appealed to all men who were anxious to fight oppression and to try and realise the Kingdom of Heaven on Earth to follow his example."3

The Labour Party, like the ILP, welcomed Wilson with open arms. The local press took a cynical view of the Labour Party's motives: "He was made leader in the hope that such an eminently respectable figure-head would divert the attention of the community from the real aims of those who profess to follow him." 4 But it seems unlikely that either Wilson or the Labour Party were planning anything so sinister. His own motives in joining the party, and the sense of inferiority many Labour men felt in their work as public representatives, could not be more clearly revealed than in a letter he wrote to the leader of the coalition group on the Sheffield City Council, pleading for a higher allocation of aldermanic seats to the Labour Party: "Most of the members of the Labour Party have never had that opportunity for business training which has fallen to the lot of most of the members of your party [...] increased Labour representation is bound to come, and it is to everyone's advantage that an attempt should be made now to so educate and make use of the material which is available, that the men and women who are elected now should be utilised in training others in the future."5

Beneath Wilson's transfer of allegiance, and the Labour Party's welcome, there ran a profound sense of continuity, of fighting oppres-

1 Cecil Wilson to C. P. Trevelyan, 25.3.18, Trevelyan Papers, Newcastle University Library.

2 "Why C. H. Wilson joined Labour", in: Sheffield Independent, 26.11.23.

3 Labour Leader, 5.12.18.

4Sheffield Daily Telegraph, 28.10.22 (article signed "Citizen").

s. Cecil Wilson to Councillor Simpson, 3.11.20, Labour Group Papers, Sheffield City Council. 
sion, and educating the people for the responsibilities of the new democracy created by the 1918 Representation of the People Act. His transition, like their original commitment, was not a question of a conversion to Socialism, or even of the victory of a Socialist generation, but one of shared idealism and conviction of the need for new moral values in industry and politics.

Arthur Ponsonby, a similar but better known figure, joined the Labour Party after a career which included being a page boy to Queen Victoria and parliamentary private secretary to Campbell-Bannerman. He joined the Union of Democratic Control, mingled with the Labour leadership in the "1917 Club" and the ILP, and became an undersecretary at the Foreign Office in the first Labour government. In Sheffield he and Wilson provided an element of experience and respectability that was very useful to the local Labour movement, but it would be inaccurate to represent either these ex-Liberals, or the "old" Socialists as having been dramatically changed by the encounter.

The trades councils in Yorkshire provided the focal point for trade union participation in politics, and membership often overlapped with the ILP. But the trades council secretaries, who were crucial figures in sustaining the flow of union branch funds into political channels, and in building up the organisational framework which made Labour's post-war success possible, tended to be quiet men, dedicated to organisation, and deeply committed to the improvement of working class conditions. They seldom participated in debates about policy, means or ends, and yet never faltered in their work for independent working class representation.

Moses Humberstone, born in 1861, rose through the branches of the steel unions to become President of the National Steel Workers' Association, and Secretary to the Sheffield Federated Trades and Labour Council. He served on the City Council, and became Secretary and Whip to the Labour group. Without his solid organisational effort the radical political involvement of his colleagues would not have been possible. G. A. Boothroyd, an ex-textile operative, was Secretary of the Huddersfield Trades and Labour Council, and although he was interested enough in the ILP to be Superintendent of the Huddersfield Socialist Sunday School for $12 \frac{1}{2}$ years, and served on the Borough Council for ten years, his contribution to the agitation and propaganda in which his colleagues Wilfrid Whiteley and Fred Shaw (both active figures in the trades council) were so deeply immersed, was very small.

Walter Barber cooperated actively in organising the various demonstrations, protests, and social activities with the ILP, which 
dominated politics in Bradford. Although he stage-managed innumerable joint committees, he was seldom eloquent on non-trade union subjects. He produced a pamphlet ${ }^{1}$ on the work of his Union (the Amalgamated Society of Dyers), and served as Lord Mayor for six months, but seldom made a political remark. But without the commitment of these union organisers to working class representation, the more politically-oriented leaders of the movement might as well have saved their breath. The conviction that there was such a thing as a "Labour Movement", and that it needed direct political representation, was crucial to Labour success in Yorkshire.

Not all trade union leaders were so quiet. Ben Turner was the giant of the Heavy Woollen District, and his campaigns in the nineties' and the early years of the twentieth century, supported by the propaganda of the Yorkshire Factory Times, were largely instrumental in converting trade unionists to the idea of a "Labour Movement". He became MP for Batley and Morley after the war, and was secretary of the Yorkshire Federation of Trades Councils, which attempted to bring closer cooperation and unity into Labour politics in Yorkshire. It met too infrequently (twice yearly) to be really successful, but it did bring the leaders in many Yorkshire towns together.

Marxist or revolutionary groups were able to play only a limited or peripheral part in the political life of the West Riding. Revolution was unable to hold its own as a viable political alternative. Many of those who, for a while, were active spokesmen for revolution, were often drawn by the force of circumstances into the Labour Party. Both these points are illustrated in the career of Fred Shaw, who was among the more prominent of the Yorkshire Marxists. Born in Lindley, near Huddersfield, he was a key figure in the Amalgamated Society of Engineers (and later the Amalgamated Engineering Union) organisation in Yorkshire, and served as President of the Huddersfield Trades Council from 1919-20 and from 1922-29. He was national chairman of the British Socialist Party in 1918, and a founder member of the Communist Party's national executive. But at the end C. R. Attlee (then Prime Minister) wrote to Shaw's widow: "The work of such men as your husband enabled the Labour movement to reach its present proud position", 2 which was tantamount to an acknowledgement of Shaw's rehabilitation.

Fred Shaw certainly seemed revolutionary enough in his articles, and sometimes his speeches. At Manchester he firmly dismissed the advocates of the single land tax: "When our friend talked about the

1 Notes and Explanations of the Workmen's Compensation Act (1906).

${ }^{2}$ C. R. Attlee to Mrs Shaw, 30.1.51, Fred Shaw Papers. 
taxation of land values he ought to realise how very small our revenue from land is compared with industry. [...] While we are worrying about middle class taxation and remedies, capital is increasing its power."1 His attitude towards "moderates" was antagonistic, and he described their dilemma without compassion: "The English Socialist Movement looked for progress on the lines of social reform, but the evolution of social organisation extended independently of the politician, who always acted under social pressure."2

But something dramatic happened, quite apart from his disillusionment with the eternal conspiracies of the Communist party, which he offered as his reason for resigning from the party. He had travelled so far that he could declare: "I am a member of the Labour Party, whose programme and policy I shall support." 3 The measure of this change of heart can be seen by comparing two statements he made about trades councils. In 1919 he wrote: "The local Soviet is a possibility. In England it will be the trades councils, if they act, but otherwise a new form will develop." ${ }^{4}$ By 1924 he had come round to the opinion that "trades councils [...] assisted greatly in the changing of the struggle from the industrial to the political field". ${ }^{5}$

External factors might account for Shaw's loss of radical energy. He stood as Socialist candidate for Greenock in 1918, and won 2,542 votes out of a poll of over twenty-two thousand. He was sacked for taking time off work to pursue his candidature. It must have been a salutary indication to him that the "revolutionary" assessment of the situation was hopelessly wrong. The Greenock paper that had reported his speech from the same platform as Willie Gallacher had believed in the possibility of success: "his uncompromising advocacy of revolutionary Socialism, his declarations against intervention against revolutionary movements anywhere, and his treatment of political questions in terms of workshop economics are winning all along the line." This was as incredible after the December 1918 election as it had seemed cogent before it. In 1921 Shaw failed to secure the affiliation of the Huddersfield Communist branch to the local Labour

1 Fred Shaw, Report in Plebs of a National Conference of Working Class Associations, Manchester, May 10th and 11th, 1918, Press Cutting in Fred Shaw Cuttings Book, hereafter cited as FSCB.

2 Fred Shaw, Speech to the Marsden Socialist Club, 3.11.12, FSCB.

${ }^{3}$ Fred Shaw, Longwood Ward Municipal Election Address, 1.11.23.

Fred Shaw in The Call, 1919, FSCB.

5 Fred Shaw, "The Future of Trades Councils", in: 39th Annual Report of the Huddersfield and District Trades and Labour Council (1924).

- Press Cutting, 23.6.18, FSCB. 
Party by 25 votes to $10 .{ }^{1}$ His political career was almost continually discouraging.

But there was more to it than this. For all his blustery, self-declared Marxism, Shaw was never the revolutionary he claimed to be. His speeches with their elaborate references to Newton and astronomy, seldom asked for the overthrow of existing institutions, and his election addresses contained lists of "reforms" that would be necessary before the working class could operate the British Constitution. His emphasis was upon bringing the working class into politics, not upon the Marxist analysis of bourgeois society. He genuinely believed, as he declared to the electors of Greenock: "the great fundamental fact for their [social problems] solution would be found in the working class remaining true to themselves." 2 There is much more reference to the proletariat than to its dictatorship. It is easy to see how close this brought Fred Shaw, after the war, to those Labour Party speakers who were stressing the importance of specifically working class representation, and reforms to help the working class. Shaw may have been more sophisticated than many Labour men in suspecting that technical development could have very painful consequences for the working class, regardless of the political machinery, but this was hardly the same thing as recommending revolution, or adumbrating the labour theory of value. He was perceptive enough to observe: "there was the greatest volume of unemployment, and this was in an age unparalleled in scientific development", 3 but his sympathy with the outlook of the post-war labour leaders prevented him from developing this into a thorough-going critique of capitalism.

Shaw's involvement in politics worked against his energetic radicalism in the same way. His proposals for the Town Council or even Parliament were far from dramatic departures from standard Labour policy. In his Fartown manifesto in 1918 he urged constitutional reform, ${ }^{4}$ and the rest of his programme, including the abolition of the Defence of the Realm Acts, the initiation of free state loans for housing schemes, and the nationalisation of the mines, land, quarries and transport, was decidedly mild. During his term on the council, he served with distinction on the tramways, gas, electricity and finance

1 Minutes of the Special General Committee of the Huddersfield Labour Party, 23.8.21.

2 Speech at Greenock Town Hall, 5.8.18, FSCB.

3 A pre-war speech in the Worker, FSCB.

4 Fartown Ward Municipal Election Address, 22.11.18. He called for the abolition of the cabinet, the House of Lords, and the creation of a Department of Health. But Fred Jowett went at least as far in the Bradford Manifesto on the machinery of government. 
committees, ${ }^{1}$ a sobering education for a revolutionary. In fact, his semi-Marxist instincts did not equip him with an alternative programme. His explanation of unemployment after the war, for example, would have been acceptable to both Ponsonby and Wilson. He argued that: "The whole basis of the present dislocation and decay of our industrial and social life lies in the war indemnities and war debts."2 Although Fred Shaw was an instinctive rebel, challenging capitalism and his employers at every step, he found himself drawn towards the Labour Party. Far from being a hot-headed extremist, he was as much part of the consensus within the Labour movement as Snowden or Jowett.

If, then, revolution was never a sufficiently convincing alternative to attract and hold even those who were temperamentally rebellious and intellectually interested in Marxism, it begins to seem unreasonable to discuss the ideas of Labour leaders in terms of "evolution" versus "revolution". If reformism was the starting point, rather than the conclusion of the debate, the simple statement that there was a consensus for reform will neither assist a further analysis of Labour ideas, nor explain how this consensus was able to provide a basis for an accommodation between Labour's sectarian supporters and great party aspirations.

The men who supplanted the Lib-Lab generation and who controlled the fortunes of the Labour movement after 1918 were agreed in their enthusiasm for change, despite their divergent backgrounds and temperaments. "Socialism" was the word that gave this essentially vague enthusiasm the cohesion and force of a political programme and converted moral indignation into a consensus upon which a national Labour Party might build. But the precise nature of the consensus has hitherto been ignored.

The common starting point for these men, upon which they founded their analysis of society and the role of politics was the evolution of modern industry. The analysis offered in J. A. Hobson's Evolution of Modern Capitalism was widely accepted. Tom Myers, who fought Spen Valley against Sir John Simon, argued that his distinguished opponent had "tacitly admitted the Socialist contentions that modern industry tends towards monopoly, that private monopoly is against the public welfare, and that the only public safe-guard against the evils of private monopoly is public ownership and control". ${ }^{3}$ Laissez-faire

1 Testimonial by J. S. Armitage, 27.7.22, Fred Shaw Papers.

2 Fred Shaw, Longwood Ward Election Address, November 1923.

3 Tom Myers, Liberalism and Socialism: An Open Letter to Sir John Simon, TUC-Labour Party Joint Publication (1923). 
economics were seen as inadequate, finally exposed by the war. Myers believed that: "The old economic law of supply and demand upon which Liberalism based much of its political faith, stands a shattered wreck before the ramifications of the trusts and combines." 1 C. P. Trevelyan felt, in 1918, that: "This war has revealed the failure of the social and economic system on which our modern world has based itself."2

Industrialisation, aided by the innovations of modern science, was crushing the rhetoric of the classical economists under foot, and its natural evolution would lead to powerful trusts and monopolies. Philip Snowden pointed out what most felt they knew: "The advantages which have been brought by these scientific discoveries and mechanical inventions have not gone to the masses of the people, but have been appropriated by a small section of the nation."3 Man's power over nature had been vastly extended in the course of industrial development, and this progress was attributed to the impact of modern science on machine technology.

Although this insight owed a great deal to Marx, the vision of industry "evolving" did not carry with it an insight into the role of labour, or the relationship between capital and labour in production. Snowden willingly conceded that Marx was responsible for the key idea of modern socialists: "From this theory naturally follows that of the socialisation of capital. The concentration of capital is preparing for the social ownership and control of it". "But he hesitated to acknowledge that writers had substituted science for the labour theory of value in explaining industrial development.

A generalised idea of "progress" supplemented the notion of technological development to provide the Labour movement with a primitive concept of growth and the material results which might follow from it. The transition to socialism was necessarily glossed over. It was assumed that Socialism would evolve much as industry had done, an automatic and natural development, once the involvement of the working class was guaranteed by a full franchise. Snowden outlined the way it would happen: "the next social system in the order of evolution must be one where associated effort will have succeeded competition in industry, and where industrial capital will be collectively owned and controlled." 5 The natural consequence of technology would, it was assumed, be a more equitable order of things.

1 Ibid.

2 C. P. Trevelyan, Election Address: Elland, 1918.

3 Philip Snowden, Socialism and Syndicalism (London 1913), p. 19.

Ibid., p. 71.

5 Ibid., pp. 80-81. 
In other words, progress. Harry Snell saw it as a question of social efficiency: "The idea of social efficiency, the conception of progress as being due to social rather than individual heredity never entered into the head of these deniers of the ideal. Yet that alone is the secret of progress." 1 Progress was more or less inevitable. Snowden was confident that: "Competition contains within itself the germs of its own destruction. The creation of trusts shows the admitted failure of the capitalist system. [...] The present industrial system is one stage in economic and social evolution. [...] These social forces are on our side, and we shall continue to work in harmonious cooperation with them, certain that some day there will be established an economic and social system where individual ambition and private enterprise will find their satisfaction, not in the amount of tribute they levy on their fellows, but in the greatness of the service they render to them."2

Fred Shaw, as we have seen, was critical of the notion that science brings wealth for all in its train. He argued that: "When we study Capitalism and its growth we find certain general movements, which make it impossible for any lasting amelioration to take place, so far as the working class is concerned." 3 The Labour movement chose to ignore the "general movements" and saw no reason why it was impossible to foresee any lasting "amelioration". Shaw himself was tempted to believe that there might be a "tendency" to progress, which would, in the end, deal with problems automatically. As he put it: "Sociology, that science which has to deal with the social process, gives us a view of man slowly and laboriously understanding and conquering nature."4

Shaw's scientific socialism was rooted in the comparison of social and organic evolution. His vision of an evolving social science doing for society what Newtonian and Darwinian physics and biology had done for science prevented him from following his criticism of Snowden's beneficent progress any further. But for most local leaders it was unnecessary to go so far as this. Harry Snell was convinced that: "the law of progress is on the side of righteousness."5 Adaptation was all that was needed: "The principles of natural selection operate in the social as in the biological world, and institutions, like organisms, survive only as they adapt themselves to new conditions."6

1 Harry Snell, "The Cult of Blood and Power", in: The Worker, 15.6.18.

2 Philip Snowden in Hansard, 20.3.23.

3 Fred Shaw, letter in Yorkshire Factory Times, 30.9.09.

4 Fred Shaw, letter in The Worker, October 1917.

5 Harry Snell, Cooperation and the Moral Code in Industry, lecture 4.1.19, issued by the Education Committee of the Huddersfield Industrial Society.

- Ibid. 
Men like this believed that Socialism was a system of social organisation which would automatically yield a better order of things. When J. H. Hudson called Socialism the "spirit and science of working class emancipation"1 he was expressing a popular expectation. Socialism was the order of society towards which industry was tending: in it the working class would be free. This amounted to a theory of industrial change, which could bring class into politics without involving any radical surgery on the existing order. In a way it is surprising that such passionate, idealistic humanists should have been happy with such a mechanistic view of industry.

The political implications of this "technical determinist" formula were more controversial. The role of the politician seemed, at first, rather limited. But some writers argued that progress could not be trusted to work out its own destiny, and that the working class should develop a more sophisticated understanding of industry, and apply this knowledge to political argument. William Leach argued that: "The future welfare of the worker can only be secured by taking part in the control of the industries which determine both his health and economic position."2 Others felt that a revolution of the mind would be a necessary prelude to the new society which industry was in the act of creating. The task of socialism and socialists was to help prepare public opinion for the new moral order. Snowden believed that: "A Socialism [...] which does not aim at arousing and developing the moral consciousness of man will never succeed in gaining and retaining the support of human beings. Socialism must be presented not merely as a demand for changes in the economic structure of industry and society but as a movement for the socialisation of our lives, our hearts, ourselves." 3

Socialists saw themselves as preparing the ground for the "socialisation of our hearts". C. H. Wilson, for example, felt that as: "the social and industrial world were not run on New Testament lines [he] wanted to make his stand with those who were trying to build up a new world of righteousness, honesty, truth and freedom". 4 But this was not a clear issue. Sometimes it was argued that the change would be as a result of moral indignation with the existing order. Snowden argued: "The moral cause of the industrial unrest was the determination of the workers to no longer be regarded as merely a part of the

$1 \mathrm{~J}$. H. Hudson in the Labour I.eader, 14.8.19.

2 William Leach, How to Reconstruct Industry (Accrington, 1917).

3 Philip Snowden in the Labour Leader, 6.11.19.

$4 \mathrm{C}$. H. Wilson at his meeting for adoption as Parliamentary candidate, reported in the Sheffield Independent, 6.11.22. 
industrial machine, but to have a share in the produce of their labour."1 Harry Snell argued that: "Labour with its social idealism, with its belief that the human spirit could produce a better world" was a worthy opponent for a "Capitalism which lived for gain, profit and self". ${ }^{2}$ Arthur Ponsonby shared this belief that the system would change, not the men: "The Labour Party had no ready made scheme for the establishment of Heaven on Earth; but they contended that present evils and injustices could be remedied."3 There was another position. The political situation was such that Labour had to win over public opinion before the changes in society they wanted could take place. This would not be a moral revolution, although it would have moral implications; it was simply a politically necessary step towards seeking consent. MacDonald put this clearly: "We can only lay foundations and educate. We can only do what public opinion will allow us to do."4

There was also the sense in which Socialism was expected to provide the ideology of collectivism as liberalism had once provided the ideology of laissez-faire. In reviewing a book by J. A. Hobson, Frederic Keeling described this concept: "The ethical ideal which is replacing it and which is the counterpart of Mr. Hobson's conception of the industrial system is best expressed by the French term 'solidarity'. It represents another ideal of character, another way of life. It comprises both what Mr. H. G. Wells means by the 'sense of the State' and what Edward Carpenter calls 'Democracy'. It is the spirit of the future." 5

This argument about industrial change ignored class. Occasionally it was challenged on these grounds. Fred Shaw "urged the Conference to remember they were working class delegates representing a movement upon the eve of power, and consequently they ought to have a social outlook in conformity with such possibilities." ${ }^{6}$ To this, Snowden was able to offer the quite legitimate reply that: "Shaw, the Huddersfield delegate, who talked revolution all the time [...] when election time came round got elected upon the question of middens."7

In practical terms those who urged greater attention to the position of the working class were always trapped when they were asked to

1 Philip Snowden in The Worker, 29.3.19.

2 Harry Snell in The Worker, 7.12.18.

3 Arthur Ponsonby in the Sheffield Independent, 7.11.22.

4 J. R. MacDonald, The Real Issues of the General Election (1923, speech at the Hotel Belgravia, 1.11.23, printed as a pamphlet).

s F. Keeling, "Mr. J. A. Hobson's Economics", in: Socialist Review, August 1909, p. 454.

- The Call, 1922, Report on No 9 Divisional Conference of the ILP, Conference on Local Government, held March 1922, FSCB.

7 Ibid. 
suggest alternative forms of political activity. Advocates of the "industrial development" argument were seldom embarrassed by a "class" emphasis. Snowden, for example, argued that class war could only destroy the "spirit" necessary for Socialism, and declared: "Such a struggle cannot develop among either of the parties to it that social spirit which is the prime essential for a Socialist community." 1 The argument is a familiar one. MacDonald himself reckoned that: "Humanity unites the capitalist and his workmen, industrial interest divides them but a comprehensive sociology joins their functions into a system of commercial ownership and control."2 It was industrial unrest, not industrial labour, which he blamed for the disharmony in capitalist society. Rarely were the implications of this kind of argument worked out in greater detail.

Some of the difficulties of resisting this version of the causes of industrial change are illustrated by the political fate of Alfred Barton, who successfully challenged MacDonald's technical socialism at the June 1918 Labour Party Conference. MacDonald, as party treasurer, moved a resolution on The Need for Increased Production. It ran: "the Conference recognises that it is vital for any genuine social reconstruction to increase the nation's aggregate annual production" ${ }^{3}$ This was to be achieved by "(a) the elimination of every kind of inefficiency and waste; (b) the application both of more honest determination to produce the very best, and of more science and intelligence to every branch of the nation's work". "In his proposing speech MacDonald said that the Labour Party asked for: "a reconstruction, a reorganisation - nay, for a regeneration of society". ${ }^{5}$

This was the essence of the consensus. Science applied to industry would ensure a volume of production sufficient to meet the needs of all - machines would regenerate society, and the human beings must be prepared for the day when the transformation would come about. The existing means for generating wealth were accepted in principle, and science, it was assumed, would give a new lease of life to machine production.

At the Conference Alfred Barton, a Sheffield Socialist agitator, put forward an amendment which threatened the basis of the whole motion. In Yorkshire, he had a reputation for cantankerous eccentricity after his performances in the City Council chamber between 1908-11 and between 1913-20. He knew Morris and Kropotkin, founded the

1 Philip Snowden, Socialism and Syndicalism, p. 78.

2 J. R. MacDonald in the Socialist Review, October 1920, p. 359.

3 Labour Party Conference Report, June 1918, p. 44.

Ibid.

5 Ibid., p. 45. 
Socialist League in Sheffield, presided over the ILP, and lost the Park Division in 1918 by the margin of 12,339 to 3,167. In a sense he was the first of the Socialists in Sheffield. A local paper later recorded: "When first Ald. Barton appeared on the City's municipal horizon, he was a flaming portent - an extremist as extremism went in those days." 1 Barton's great moment came when he seconded the amendment to MacDonald's motion. The clause he proposed to insert read: "the socialisation of industry in order to secure". ${ }^{2}$ Barton told the Conference that there was a "great outcry about the need of increased production, but the capitalists' idea was that when the war was over they would have to spend all their time in paying the war debt, and increased output would mean increased profit to them. [...] Labour had to fight for its own ends, and not listen to the camouflage of political theorists. If the amendment was not put in the resolution it would simply mean they would be playing the capitalists' games, and that the capitalists would use the Labour Party to back their end up in every possible way." 3 This was a powerful argument, and the amendment was carried with a substantial majority. But no vote could dent such a well-established fabric of belief. There were many calls in the following years for increased production, to be achieved by various means, from the counter-cyclical tactics of underconsumptionist theory to the counter-Versailles arguments of the Internationalists and the pacifists, and there were equally many protests that the party was not implementing its promise to extend public control. But the contradictions were never again so clearly exposed.

It is surprising that Barton carried his successful argument no further, and puzzling that his point was so willingly accepted and forgotten. The character of the man is part of the answer. He was a dilettante, an insurance agent working for the working classes, a theorist and literary enthusiast helping the education of his less fortunate brethren. He later served on the library and education committees with distinction, and no doubt much personal satisfaction. He wrote a book, $A$ World History for the Workers, which revealed how deeply immersed he was in the proposition of "educational" Socialism. $\mathrm{He}$ believed in education for social reform, as well as political activism. Both points helped to make him ineffective as a critic of the consensus. Once he was involved in politics, appearing on committees, writing articles, he began to accept part of the "parliamentary", "educational" case. It was not possible to combine education with a critical account of MacDonald's Socialism; participation in politics made it impossible

1 Sheffield Daily Telegraph, 11.12.33.

2 Labour Party Conference Report, June 1918, pp. 45-46.

3 Ibid. 
to denounce politics as such. Barton's idealism, his belief in the possibility of a new and better life, also served to thwart him. The "ethical" Socialism of the ILP captured even those men who were not attracted by the sentimentalism that went with it. In his World History Barton argued: "The blind passions - Sex, Hunger and Conflict, tend to become sublimated into Intelligence, Ideality and Social Love, portending, perchance, the evolution of a new psychic being, the super-organism, Humanity". ${ }^{1}$

Given such possibilities of moral improvement, the political agitator was caught in two frames of mind. Might not intelligence and education alone produce the moral will necessary for the new order of society? Might aggressive political action prove unnecessary? And what would the value of the redistribution of wealth or reorganisation of industry be without the creation of a new moral being? This was MacDonald's point, and it touched even those with the pertinacity to see the weakness of his arguments about the evolution of industry. Barton was thus caught in his own personality, and the double argument about a "new world". He could not decide which should come first - the change in industrial organisation, or the moral revolution. The attractive "means and ends" educational formulation was enough to make such born rebels as Barton doubt the value of their own dissent. In any case, their energy could do no more than help turn the wheels of "propagan$\mathrm{da}$ ", and this left the matter unresolved.

The educational and moral implications of "technical" Socialism were comprehensively described by the ILP in a memorandum to the International Socialist Congress at Geneva in 1920: "The weakness lies in the bad education of democracy and the imperfect state of Socialist propaganda. [...] the weakness of the Socialist movement cannot be made good by revolution, which with a dictatorship may succeed for a time, but which in the end has to base itself on public acceptance. Therefore the revealed weaknesses of Democracy can be overcome only by persistent education and propaganda, and by the strenuous activities of the Socialist and Labour groups in the various Parliaments. [...] the Party, however, sees no reason for departing from its old position, that until socialist propaganda influences public opinion, and until socialists are chosen as representatives on public bodies, no secure basis for the Socialist State can be laid."2

These assumptions and arguments were by no means confined to

1 Alfred Barton, A World History for the Workers (London, 1922), p. 15.

2 Memorandum on Socialism and Government for Submission to the International Socialist Congress at Geneva, 1920, in I.L.P. Annual Report, 1919, Appendix 1. p. 28. 
the ILP, or a small band of MacDonaldites. They recur in one form or another in countless speeches and articles by Yorkshire Labour agitators, and underpinned the economic arguments based on the progress of modern industry.

Oliver Smith inferred that the chief lesson of the election of 1918 was "educate, educate, educate". ${ }^{1}$ Fred Jowett believed: "Our weapons are education, agitation, organisation." 2 The local press saw Wilfrid Whiteley as a "hot gospeller" whose desire was not to "make "little Socialists' so much as to encourage the youngsters under his care to think for themselves". ${ }^{3}$ A Labour politician was almost automatically a "propagandist", and his task was generally to "educate". Most of the leading Yorkshire representatives of the ILP and the Labour Party, excepting the miners of South Yorkshire, had experience of the peace movement, where they had been in a minority, and where even propaganda was severely restricted by the operation of the Defence of the Realm Acts. Snowden, Jowett, Leach, Hudson, Ponsonby, Wilson, Whiteley and Shaw were only the most prominent of many who had learned that propaganda might be the basis, and often the sole form, of political action during the war, an experience to confirm the ideas formed in pre-war days. Labour's sense of its minority status, of the absolute supremacy of propaganda, therefore survived into a period when it was less relevant. After 1922, when Labour had 140 or more seats, it was clearly not restricted to propaganda. But the war hardened attitudes acquired in the early days of the movement.

Expectations of education were, nevertheless, diverse and confused. The most common assumption was that education would help spread throughout the working class the sense of being part of a "Labour movement", and to enable it to claim its political inheritance. The creation of what was called an "educated democracy" was felt to be an essential preliminary to political reform. Occasionally coupled with ideas about the democratic control of industry, the aim was to educate the workers so that they would be able to use their political power. This involved making people aware of their social identity, and agitating within the Unions to make them aware of their power and potential. Ben Turner, for example, argued that: "It will need the growth of intelligence and experience to bring all industry under "common ownership'."4

J. H. Hudson felt that: "Socialism depends not only upon the growth of a Parliamentary majority, but also upon the development of

Oliver Smith in The Worker, 4.1 .19 (Editorial).

${ }^{2}$ Fred Jowett in the Municipal Supplement to the Bradford Pioneer, 19.10.23.

3 Huddersfield Examiner, 16.9.24.

- Ben Turner in the Labour Leader, 10.1.18. 
a new spirit in the Trades Unions themselves, and it will be readily conceded that educational work must go on at an increased rate inside the Trades Union branch". ${ }^{1}$ Jowett saw the problems of Labour educators in still more dramatic terms: "the biggest hindrance we all have to contend with is the slow-moving mass mind, which is too full of the thought of its daily bread to see far-off visions of nationalisation [...] But if he can be made to feel his every-day wrongs, and demand redress, he will move. [...] When he finds his consciousness and his will, then Labour in Parliament will speak with the imperial voice of millions." 2

For Jowett the problem of enacting Socialism was secondary to creating a public opinion which could see beyond the end of its nose. In this way mere political rights could have a higher priority than Socialism itself, because they would be more important in the business of creating this enlightened public opinion. W. Hirst, the Cooperative candidate at Bradford, did not distinguish between Socialism and the physical and moral improvement of the people: "If those principles were not part of a movement of great magnitude for the uplifting of the people, then he knew of nothing which would tend to that end."3 The Labour agent in Huddersfield carried this to its logical conclusion when he said that Labour's aim was, simply, "by a full, free and scientific system of education to materially advance the rising generation". 4

Alderman Hardaker, who ran against C. P. Trevelyan at Elland in $1918,{ }^{5}$ did hope that this demand for political rights through education would extend even further: "The people themselves should be so educated that they would be put in a position to control the industries of the country for the welfare of the people."6 For others it was enough to establish that the people had a shared interest as workers, and that class was relevant to politics. The Leeds Weekly Citizen urged its readers: "Bring action to bear directly upon every working man and woman you come into contact with; convert them to an intelligent consciousness of the position and see to it, as far as is humanly possible,

${ }^{1}$ J. H. Hudson, "A Message to the Trade Unionists of Huddersfield", in: 39th Annual Report of the Huddersfield Trades and Labour Council.

2 F. W. Jowett in Labour Party Conference Report, 1922, p. 174 (Chairman's Address).

${ }^{3}$ Bradford Daily Telegraph, 10.12.18.

${ }^{4}$ Letter from W. B. Hargreaves in The Worker, 16.11.18.

${ }^{5} \mathrm{C}$. P. Trevelyan did not become a Labour man until after the election, although he had publicly announced his Labour sympathies. He hoped that the Labour man would stand down. The Elland Party was not happy with this, however, and ran their own candidate.

- Brighouse Echo, 6.12.18. 
that there is not a single one amongst your list of acquaintances who has not had an opportunity of learning how to use his or her vote at the ballot box in an intelligent class-conscious way." 1 Philip Snowden himself accepted the need for a class bias in Labour propaganda. $\mathrm{He}$ claimed that the ILP "has contributed more than any movement in modern times in Great Britain to the development of a social consciousness and to the political and economic education of the working classes". ${ }^{2}$

By contrast, others believed that socialism could be created only from within, by a process of spiritual renewal and re-education in new values. Moral progress would equip man for technical development.

The first Labour Lord Mayor of Bradford, for example, felt strongly that political revolution was impossible, and that the hope of Labour should lie in education. "It is education which produces the best in our civilisation. Revolution won't thrive with an educated democracy. Education is the driving force of reform, and we must never be satisfied until we have given to every human child, be it rich or poor, the opportunity of the highest human development of which it is capable."3 J. H. Palin, a Bradford ILP'er and later a Leeds MP, agreed. "It was said of him that he wished to see a revolution [...] but it was a revolution of thought which he sought, for during his service in France he had seen enough blood spilt without desiring to see any British blood run through troubles at home." 4 Propaganda along these lines, it was felt, was the only way to put parliamentary socialism into practice. Robert Smillie, the Miners' leader, for instance, assured his audience at Dewsbury that: "His propaganda was to effect a better condition of things by a revolution of mind and of thought on the part of the working classes."

But Labour did not settle for a moral revolution simply because political expediency suggested it so strongly. Often, the creation of a new social ethic was seen as the essence of Socialism itself. Arthur Ponsonby, for example, claimed that Socialism was "in itself a religion". ${ }^{6}$ A. V. Alexander was not embarrassed to find himself showing that the "life of Christ was the working-man's life of that particular period". ${ }^{7}$ Spiritual revolution therefore carried the case for education

" "The Necessity for Propaganda" (Editorial), in: Leeds Weekly Citizen, 10.12.20. ${ }^{2}$ Philip Snowden in ILP Annual Conference Report, 1919, p. 54 (Chairman's Address).

${ }^{3} \mathrm{~J}$. Hayhurst in Bradford and District Trades and Labour Council Annual Report, 1919.

4 J. H. Palin in Bradford Daily Argus, 5.12.18.

5 Leeds Weekly Citizen, 10.5.18.

- Sheffield Daily Telegraph, 4.11.22.

7 Sheffield Cooperator, April 1923. 
to the centre of the stage - it was the base of Socialism, without which any efforts at a socialist society would be predestined to failure.

Attitudes towards the theoretical significance of education were, however, varied. Some welcomed education as the means by which a "new way of life" might be achieved, the very means of Socialism others were only swayed because it was all that was open to them once the option of political revolution had been rejected. Others saw education as preparing the people for the new order machine technology was creating. Fred Shaw argued that: "Progress has far outstripped the moral evolution of the race", ${ }^{1}$ and felt that: "Never in the history of industrialism was it more imperative than now for an enlightened working class [sic]."2 At times the new moral order became indistinguishable from the fulfilment of the political aspirations of the working class.

There were also practical reasons for encouraging propaganda. To win power, Labour had to publicise its ideas and plans. But apart from this, many local leaders found it barely credible that ordinary working people voted for the parties which, from a Labour point of view, were so obviously associated with profiteers, business, and the employers. Their reaction was to imagine that straightforward ignorance of the facts of political life was the barrier between the working class and its political inheritance. A great deal of propaganda was based on this simple idea. Cecil Wilson attributed his victory at Attercliffe in 1922 "to activity of propaganda, which has been going on all through the summer and continued by street-corner meetings throughout the municipal and Parliamentary campaign". ${ }^{3}$ From his point of view it was necessary "to create in the minds of the people a deep conviction that things were not as they ought to be".4 W. B. Hargreaves saw the problem with an agent's empirical eye: "The solid educative work put in during the last twenty years by the Labour and Socialist forces is beginning to bear fruit - the capitalist forces by their combinations can still delay complete victory, but they cannot stem the onward march. Unity, organisation, propaganda, steady effort, and a different story will be told within a few short years." 5

There was little else that Labour organisers could do. If they were suspicious of the idea of class consciousness or a moral revolution they still could not resist the call to propaganda. In this way, the complex

1 Letter to The Worker, October 1917.

2 Syllabus of Plebs extension classes in Huddersfield, 1921-22, Fred Shaw Papers.

s "Why I won", in: Sheffield Independent, 16.11.22.

Ibid., 7.11.22.

5 "A Letter on the Municipal Flections", in: The Worker, 25.1.19. 
assumptions wrapped up in the Party's expectations of education slipped through as a superficially ordinary activity, part of the business of being a political party. It was not always realised that the equation of education and Socialism concealed a vision with far deeper implications than a mere reiteration of the good points of a Kingdom of Heaven on Earth. Harold Armitage's remark that: "The ultimate aims of education and socialism were much the same [...]. The educationist sought the good of each member of society in developing both the latent capacities and all sides of his nature", 1 pointed in directions that its author barely suspected.

For the local leadership the 1918 Representation of the People Act opened new possibilities in politics which it was not slow to perceive and grasp. The 1918 electorate included millions of previously excluded unskilled workers and their wives. It was reasonable to expect a high proportion of the new voters to be Labour-inclined. If the new millions were ordinary workers, it was necessary to bring home to them a sense of their own identity and destiny, and to show the relevance of that identity to politics. For this reason the local appeal was primarily to the working class.

Labour workers set out to convince the public that there was an identifiable working class with a common experience and common interests which transcended community or religious rivalries. Wilfrid Whiteley posed the question directly: "Working men in those parties were beginning to ask themselves whether the day had not arrived when they should be working men or women in politics as well as in their work."2 If the Coalition represented the employers, what could be more natural than that the working class itself should press its demands? Philip Snowden claimed that: "The working people of the country were becoming conscious of their own power, and were asserting their dignity." $3 \mathrm{~J}$. R. Clynes, normally associated with a classless, impartial view of Labour, admitted in a letter to the trade unionists of Bradford that the Party "has been supported in the main by working men". Ben Turner interpreted Labour and the New Social Order as a document setting out the common interest of the workers: "I hope the working people will read it, study it, and get clearly into their minds what it means to them. It is their magna carta. It seeks to

1 H. Armitage at the Huddersfield Socialist Sunday School Adult Class, The Worker, 31.1.20.

${ }^{2}$ Huddersfield Examiner, 6.12.18.

3 Ibid., 8.12.23.

- Bradford and District Trades and Labour Council Annual Report, 1920. 
alter the whole relationship of men to one another." 1 But it was not only the man with a working class background or trade union experience who stressed the importance of working class identity in politics. Arthur Ponsonby argued that: "People were beginning to realise that the subjection of the workers was not an arrangement of nature but of man. [...] So long as the workers were in a position of subjection, we could never get a social order where a decent life was possible for all citizens of this land."2

Once it was proved that the working class existed, Labour's aim was to establish that its interests were directly opposed to the government and its wealthy supporters. Class consciousness led to class solidarity. Labour wanted to prove that there were two classes: one rich, one poor; one idle, the other industrious; one living on rent, interest and profit, the other on bread and dripping. Wilfrid Whiteley declared that it was "now a straight fight between Labour and financial interests who had organised to keep out Labour." 3 He asked: "Who were the people they were up against, and to whom did they send their deputations asking and demanding increased wages and bonuses? Always the employing class, who even that day were the supporters of the Coalition candidate."4 Fred Jowett declared that: "I believe in the solidarity of the working class", ${ }^{5}$ and feared that the war had "disclosed depravity and weakness on the part of the ruling classes far greater than were previously suspected". ${ }^{6}$ Martin Farrington, a candidate for the West Riding County Council at Slaithwaite, believed that: "We can never hope to destroy class distinction until we destroy class rule."7

Jowett had no doubts about how the workers should answer their employers: "It is not for nothing the workers are asked to stand together and vote Labour at this election."8 Alderman Hardaker was even more adamant about it: "his presence as a Labour candidate was an evidence of the revolt of trade unionist and socialist organisations against present conditions, and the desire of the workers to take on the work of their own salvation. The workers refused to be tied to the chariot wheel of the capitalist class."9 Work and citizenship were seen together,

1 Labour Leader, 10.1.18.

2 Sheffield Independent, 4.11.22.

${ }^{3}$ Oldham Chronicle, 5.12.18.

4 Huddersfield Examiner, 6.12.18.

5 Fred Jowett, Election Address: Bradford East, 1918.

- Address to the Trade Unionists of Bradford, in: Bradford and District Trades and Labour Council Annual Report, 1920.

7 Martin Farrington, Election Address (County Council), 1919.

${ }^{8}$ Municipal Supplement to the Bradford Pioneer, 19.10.23.

- Bradford Daily Telegraph, 28.11.18. 
and Jowett drew the conclusion that: "If the workers and the community are doomed to carry the whole horde of parasites who live on rent, interest, and profit [...] it will be ages [...] before the workers shake off the parasites". "With the war over the working class could only seek redress of its grievances through politics, and their complaints bound them together in solidarity. As Whiteley put it: "Whatever need there existed before the war for common action among the masses of the people, and it was great, there was a thousand-fold need today." 2 Hargreaves, the Huddersfield agent, spoke of the "working class party" and the "conquest of political power by the common people". ${ }^{3}$

The Labour Party hoped to politically unite these millions of ordinary people. The implication of Labour propaganda was that the entire working class should join together to elect "working class representatives" - it was not a question of a majority of working men arriving at the rational conclusion that it was in their own best interests to vote Labour. The Labour Party was presented as a working class party with working class representatives. G. A. Boothroyd hoped that the electors of Colne Valley would "be amongst those to send a workers' representative to the House of Commons at this historic election". "Harry Snell declared: "I belong to the working classes, and have practical experience of their lives and needs". ${ }^{5}$ Wilfrid Whiteley said that his first consideration would be "for the working class, whose needs are greatest [...] eight out of ten of the electors are workers, and ordinary fairness calls for an increase in the number of Labour councillors." 6 The Labour Party, despite Clynes's denial that it was an "instrument for affecting some narrow class purpose", 7 was declared by Jowett to be "challenging the old order and forcing the miseries of the common people on the attention of the comfortable classes and the government which serves the comfortable classes". 8

Moses Humberstone "recognised that they, as workers, had to unite if they were to hold their own in the city at the present time. [...] They were there as one solid Labour party which was determined to do its level best for the workers." 9 Even if politics was not actually

1 Bradford Pioneer, 31.12.20.

2 The Worker, 15.6.18.

${ }^{3}$ Ibid., 16.11.18 and 4.1.19 respectively.

4 G. A. Boothroyd to Wilfrid Whiteley, 7.12 .18 (published as a handbill).

5 H. Snell, Election Address: Huddersfield, 1910.

- Wilfrid Whiteley, Municipal Election Address (Crosland Moor), 1.11.22.

7 J. R. Clynes, "The Unity of Labour", in: Bradford and District Trades and Labour Council Annual Report, 1920.

8 Fred Jowett, "Address to the Trade Unionists of Bradford", ibid,. 1923.

- Sheffield Daily Telegraph, 28.7.20 (on the Union of the two trades councils in the City). 
polarised (owing to the persistence of the Liberals), there were Labour men who were anxious to make it so. "This was the first time there had been a bid to make only two parties in this country. One party would be the Labour Party standing for the working classes, and the other party would be the party against them"," declared Councillor Bailey, of Sheffield. Arthur Lockwood, a Sheffield cooperator who later became secretary-agent to the Reading Party, felt that the "only means of salvation was to return a sufficient number of working men to voice the views of the people". ${ }^{2}$ Sometimes this approach got out of hand, dominating election addresses and standing as the only piece of prose at the head of a list of Labour promises. Wilfrid Whiteley tied himself in knots with this declaration: "I know the life of the worker because I live it; and it is in the desire more fully to serve this great class that I offer myself. [I] shall at all times use my energies in the direct interest of the working class." 3 Alfred Barton was so enthusiastic about his devotion to this cause that he declared his faith to the most unlikely audiences. In the solid and respectable Park Division of Sheffield, where he eventually lost in a ratio of four to one, he announced that: "he had been one of the working class all his life, and had at heart the interests of the working class", and promised to "secure the working classes a just share of the wealth which they created". 4

There were few efforts to be more specific: it was generally deemed enough to be working for justice. R. E. Jones made the kind of generalised statement that tacitly supported almost every affirmation of "class interest" that has been quoted above: "If the Labour Party did not stand out for lifting the working classes into a better position than they held today it would not be worthy of the name". 5 The emphasis upon class made the Labour Party seem much more radical than it actually was. The class rhetoric disguised the Party's rejection of the class analysis of society. Labour believed in the representation of class interests but denied class antagonism as a source of social change. The demands for working class representatives, a working class party, and the discussion of working class interests amounted to no more than the call for the vote. Labour simply aimed to end the exclusion of the workers from political power. This is not to say that there was any deception or insincerity in Labour's appeal. Most Labour candidates genuinely felt that they were going into Parliament to represent the

1 Ibid., 3.12.18.

2 Ibid., 6.12.18.

3 W. Whiteley, Election Address: Colne Valley, 1918.

4 Sheffield Independent, 5.12 .18 and 10.12 .18 respectively.

b R. E. Jones at a meeting in Brightside, Sheffield Independent, 10.12.18. 
workers, and saw the Labour programme as a radical redress to working class grievances. The candidates were often as confused and deceived as those who voted for them.

Labour's claim to be a national party was not, paradoxically, in conflict with its long-standing involvement in the promotion of working class political rights. The formula of "workers by hand or brain" arrived -at in the 1918 Constitution was intended to show that Labour was antagonistic not to ordinary people who earned a living, but to unearned wealth and the financial infrastructure of capitalism. But even without this statement, the local leaders, who had grown up in the ILP and the industrial movement, felt that because Labour represented the working class it was entitled to call itself a national Party, however close to sophistry this may seem today. Harry Snell, a moderate and respectable minister in the 1929 Government, argued at Huddersfield that: " $90 \%$ of the population were working people and if it was right for any class to be represented in Parliament their right was indisputable." 1 Philip Snowden made the same point even more firmly: "The Labour Party was now a political machine of great power. It was the expression of working class opinion."2 Labour supporters felt that it was extremely unlikely either that a genuinely national party would ignore the workers, or that the workers, once in power, would behave as badly as the "capitalist" parties had done.

The emerging consensus was similarly unscathed by the volume of class rhetoric. The "educational" theory of Socialism, upon which the political Labour movement was coming to depend, worked on the assumption that before the sectarian demands of the workers could be accommodated and made "national", it would be necessary to draw the working class into politics, and involve it in the struggles of the Labour Movement. The point was that if Labour did not believe industrial society progressed through class antagonisms, its sectarian appeals and working class support could not logically produce a policy likely to undermine existing institutions. A theory of change based on science and technical innovation was inherently unrevolutionary. The working classes were to be converted to Socialism, not Socialism to the needs of the masses. It was necessary, therefore, for the working classes to enter into politics before Labour could become a national and nonsectarian party. By these means the consensus helped shape the raw materials for a new political party.

${ }^{1}$ Huddersfield Examiner, 14.12.18.

2 Snowden at the Otley Chevin Summer School, Leeds Weekly Citizen, 29.7.21. 